\title{
Saving and loan business management strategy of Satu Hati Village-Owned Enterprises (BUMDes)
}

\author{
Fransiskus Seran Nuak ${ }^{1}$, William Djani ${ }^{2}$, Petrus Kase ${ }^{3}$ \\ Nusa Cendana University ${ }^{1,2,3}$ \\ fransseran03@gmail.com ${ }^{1}$,williamdjani@gmail.com ${ }^{2}$, kasepetrus@yahoo.co.id ${ }^{3}$
}

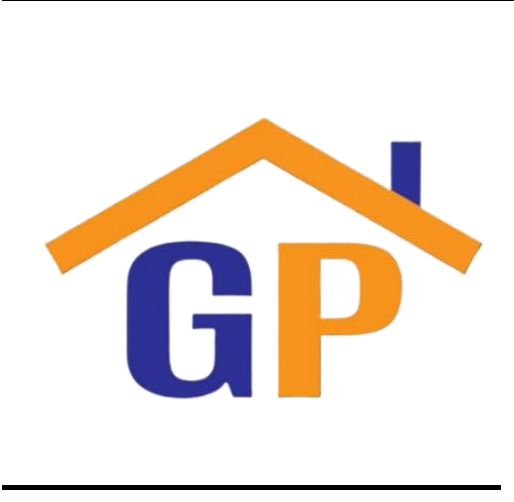

Article History

Received on 28 October 2020

Revised on 30 November 2020

Accepted on 3 December 2020

\begin{abstract}
Purpose: The purpose of this study is to analyze saving and loan business management strategy in Satu Hati Village-Owned Enterprises (BUMDes) In Naimana Village, Central Malaka SubDistrict, Malaka District.
\end{abstract}

Research methodology: This research used a descriptive research method with a qualitative approach. This research used purposive sampling technique.

Results: The results of this study found that communication and cooperation are not good enough, there are no binding rules, and recording and bookkeeping are not in accordance with the borrower's deposit.

Limitations: This research only analyzes Management Strategies for Savings and Loans at Satu Hati Village-Owned Enterprises (BUMDes) in Naimana Village, Central Malaka Sub-District, Malaka Regency.

Contribution: This research becomes information for the development of Satu Hati Village-Owned Enterprises (BUMDes) so that this BUMDes can continue to grow.

Keywords: Environmental observation, Management strategy, Savings and loans business, Strategy formulation, Village-Owned Enterprises (BUMDes)

How to cite: Nuak, F. S., Djani, W., \& Kase, P. (2019). Saving and loan business management strategy of Satu Hati VillageOwned Enterprises (BUMDes). Journal of Sustainable Tourism and Entrepreneurship, 1(2), 165-178.

\section{Introduction}

The government has a strong desire to improve the economy of rural communities, so a village local economic institution is formed by looking at the potential of village local wisdom, one of which is the formation of Village-Owned Enterprises (BUMDes) whose legal basis is Law Number 6 of 2014 concerning Villages. The government seeks to improve the village economy by looking at the potential of the village through the concept of village autonomy with the understanding that the central government gives village authority to manage their regions independently as reflected in Law of the Republic of Indonesia Number 6 of 2014, which contains four articles on BUMDes, including articles 87-90 which describe capital in managing BUMDes. In addition, the presence of legal certainty in Law Number 6 of 2014 articles $87-90$ allows villages to be able to develop a spirit of economic entrepreneurship through the development of Village-Owned Enterprises (BUMDes). The presence of Law Number 6 of 2004, especially in village development, is an opportunity to develop a spirit of entrepreneurship under Village-Owned Enterprises (BUMDes) which is managed by the government and village communities independently and democracy.

The Indonesian government is currently placing the village on the front page of Indonesia. This is certainly influenced by the issuance of Law Number 6 of 2014 concerning Villages, developing new paradigms and concepts of village governance policies nationally. The law passed at the end of 
2013 also developed the principle of diversity, prioritizing the principles of recognition and village subsidence. The objectives of the Law on Villages are in line with the vision and mission of the 20142019 national development planning which is based on President Joko Widodo's Nawacita, which calls for an Indonesia that is sovereign, independent and has a personality based on mutual cooperation.

President Joko Widodo and Vice President Jusuf Kalla have launched Nawacita, namely nine development priority agendas for Indonesia. The program created by President Joko Widodo is expected to realize the national goals of the Indonesian nation. Nawacita itself is the nine development priorities for the next five years. These nine priorities are now part of the 2015-2019 National Medium-Term Development Plan $(R P J M N)$. One of the Nawacita agendas is "realizing economic independence by moving the strategic sectors of the domestic economy", which is listed in the seventh point. Of course, this will be the basic foundation for economic development in Indonesia.

The government is currently facing many problems, one of which is development. This has always been part of the government's program every year. Every country definitely wants to increase the income and welfare of the people in order to create a developed economy. Therefore, economic development is very important to do in order to achieve these goals. The purpose of economic development is to increase intelligence, community welfare, improve living standards and serve as a strong foundation for further development. To achieve this goal, development planning must focus on the potentials that can support the economy in terms of the resources of each region. One indicator to see the welfare of society from a material aspect is through the rate of economic growth.

The Indonesian government at this time must be able to create a business that is able to support economic development healthily, both by improving the welfare of members and the surrounding community, as well as participating in building a national economic system. The development of Village-Owned Enterprises, hereinafter abbreviated as BUMDes, as an economic organization is projected to emerge as a new economic power in rural areas. BUMDes can be referred to as an instrument of village autonomy which means to develop the potential of the village by being encouraged by the village government in accordance with the capabilities and authority of the village, while as a welfare instrument, namely by involving the community in the management of BUMDes as well as a program designed by the government to improve the standard of living of a more community. BUMDes has a way of working by accommodating community activities in the economic field into an institutional form or business entity that is professionally managed, but still based on the original potential of the village through the capacity and authority of the village. BUMDes which can be the axis of village community life can be said to be ideal, because the goal is to meet community needs, be able to absorb the production capacity of the community and have open access to all village communities. The establishment of a BUMDes has the aim of being an agent of regional development and to be a driving force for the creation of a corporate sector in rural areas but with not too high production and management costs. However, it is still based on the village's original potential through the village's capacity and authority. BUMDes which can be the axis of village community life can be said to be ideal, because the goal is to meet community needs, be able to absorb the production capacity of the community and have open access to all village communities. The establishment of a BUMDes has the aim of being an agent of regional development and being a driving force for the creation of the corporate sector in rural areas but with not too high production and management costs. However, it is still based on the village's original potential through the village's capacity and authority. BUMDes which can be the axis of village community life can be said to be ideal, because the goal is to meet community needs, be able to absorb the production capacity of the community and have open access to all village communities. The establishment of a BUMDes has the objective of being an agent of regional development and being a driving force for the creation of a corporate sector in rural areas but with not too high production and management costs.

BUMDes is one of the economic institutions at the village level which basically must be established based on the strong desire of the village government to improve the economy of its people and not only based on government instructions. However, it must be based on the desires of the village community, starting from the existing potential, if managed properly, it will generate market demand. So that later, if there are certain groups in rural areas and have large capital, they will not dominate the existence of economic institutions. So the ownership of the institution is jointly controlled by the village and has the main objective of increasing the economic standard of living of 
the village community. The institutional form mentioned above is called Village-Owned Enterprises (BUMDes). Based on the issuance of Law Number 6 of 2014 concerning Villages, as mandated in Chapter X which states that Villages can establish Village-Owned Enterprises called BUMDes. Establishing a business entity must be accompanied by efforts to strengthen capacity and be supported by regional (district / city) policies that facilitate and protect this business from the threat of competition from big investors.

BUMDes is a pillar of economic activity in villages that must function as a social institution and a commercial institution. As a social institution, BUMDes sides with the interests of the community through its contribution in providing social services. Meanwhile, BUMDes as a commercial institution has the goal of seeking profit through the supply of local resources (goods and services) to the market. In running his business the principles of efficiency and effectiveness must always be emphasized. As a BUMDes legal entity, it is formed in accordance with the agreement established in the village community and based on the applicable laws and regulations. The form of BUMDes thus can vary from village to village in Indonesia. These various forms correspond to each village which has local characteristics, potentials, and resources. Further regulations regarding BUMDes are regulated through Regional Regulations (Perda) in their respective regions. Furthermore, the task and role of the Government is to disseminate and raise awareness to village communities through the provincial and / or district governments about the importance of BUMDes for improving community welfare. Through the village government, the community is motivated, made aware and prepared to build their own life.

BUMDes can operate a business space that has been regulated by Law Number 6 of 2014 article 87 paragraph 3 which states that a BUMDes can run a business in the economic sector and / or public services in accordance with the provisions of the applicable laws and regulations. This means that village-owned enterprises can run various businesses, ranging from services, microfinance, trade, and other economic development. For example, BUMDes could form a business unit engaged in microfinance by legally referring to the Micro Finance Institution Law and the Financial Services Authority Law.

Naimana Village, Central Malaka Sub-District, Malaka Regency also has BUMDes. The number of business units currently running is quite large and varied. From shops, savings and loans, agricultural and livestock services, and party equipment rental. This business is managed by BUMDes administrators in Naimana Village and is named "Satu Hati" BUMDes.

Sewhat has been stated in the Naimana Village Regulation Number 3 of 2017 concerning the Establishment of Village-Owned Enterprises. The objectives of establishing a Village-Owned Enterprise are:

1. Establishment of an independent and resilient Village Economic Institution;

2. Meget profit through Village efforts to increase Village Original Income Sources (PADes);

3. Providing services to community needs.

Satu Hati BUMDes in its management is quite good in terms of other business midwives, but this is inversely proportional to the savings and loan sector, where many people carry out savings and loan activities but are constrained in terms of returns so that the Satu Hati BUMDes funds become stuck and their management is hampered and leads to not running because the capital given to the community is mostly not / has not been paid back to Satu Hati BUMDes. This situation is clearly not in accordance with the guidelines for managing the funds which are the main source for BUMDes.

Satu Hati BUMDes, started this savings and loan activity since December 2017 until now. The source of funds for the Satu Hati BUMDes village savings and loans business comes from the Village Fund with details of the amount of funds per year as in table 1.1 below:

Table 1.1 Equity Participation from Village Funds for

Savings and Loans Businesses At Satu Hati BUMDes,

Naimana Village

\begin{tabular}{|c|c|c|c|}
\hline No. & Year & Capital Amount & Percent (\%) \\
\hline 1. & 2017 & $50,000,000$ & 54 \\
\hline 2. & 2018 & $43,000,000$ & 46 \\
\hline 3. & 2019 & - & - \\
\hline & Amount & $93,000,000$ & 100 \\
\hline
\end{tabular}


Source: Satu Hati BUMDes, 2019 Financial Report Recapitulation

Satu Hati BUMDes, within 2 years has provided loan funds to 29 people. This borrowing of funds is only allocated to the community / residents as individuals. Funds that have been borrowed must be returned for 12 months (1 year), with different amounts of funds as needed. but in its implementation, the funds that have been borrowed from BUMDes have not all been returned, the borrower is indifferent to this situation so that there needs to be intervention from various parties in the scope of the Village so that the funds that have been loaned can be returned and can be used by other villagers who need it. This can be seen in table 1.2 below:

Table 1.2 Amount of loans for Savings and Loans at Satu Hati BUMDes, Naimana Village (In Rupiah)

\begin{tabular}{|c|c|c|c|c|c|c|}
\hline No. & Year & $\begin{array}{c}\text { Capital } \\
\text { Amount }\end{array}$ & Interest & Total & Return & $\begin{array}{c}\text { Remaining } \\
\text { Payment }\end{array}$ \\
\hline 1 & 2017 & $47,500,000$ & $3,918,750$ & $51,418,750$ & $27,980,750$ & $23,438,000$ \\
\hline 2 & 2018 & $40,500,000$ & $3,633,750$ & $44,133,750$ & $17,242,500$ & $26,891,250$ \\
\hline 3 & 2019 & - & - & - & - & - \\
\hline \multicolumn{2}{|r|}{ Amount } & $88,000,000$ & $7,552,500$ & $95,552,500$ & $45,223,250$ & $50,329,250$ \\
\hline
\end{tabular}

Source: Satu Hati BUMDes, 2019 Financial Report Recapitulation

Researchers felt table 1.2 shows, the amount of funds that have been borrowed by 29 Naimana villagers that it has not been fully intended, this can be seen from the amount of loan refunds where the amount of refunds from 2017 until now is not all. So that the savings and loan business activities at Satu Hati BUMDes become stuck. As for individual data, the amount of funds borrowed, the amount of refund and the remaining loan can be seen in (Attachment). The table above also shows that there are still many borrowers who have not returned their loan funds. This is a serious problem that must be resolved so that the circulation of funds managed by BUMDes can run well.

\section{Literature review and hypothesis development}

\subsection{Strategy}

Strategy refers to the top management of the organization which is the main concern. According to Steiner \& Milner (1997: 97) in particular the strategy, namely the 'forging' of the company's mission, the determination of organizational goals by considering external and internal forces, formulating certain policies and strategies to achieve goals and ensure their proper implementation, so that the main goals and objectives organization will be achieved. The word strategy also refers to what is the main concern of top management of the organization and a success of strategy is usually not a single decision, but a network of interrelated strategy, substrategy, sub-substrategy, policy and tactical.

Steiner \& Miner (1997: 98) assume that an organization's success will depend on how well an organization formulates its policies / strategies in its developing environment, how well the organization defines its policies / strategies in writing, and how well the organization guarantees its implementation

The organization in determining its steps to success must have a strategy. The strategic objective can be one or a combination of three possibilities, namely political, organizational, and policy. An organization with political objectives means that the organization seeks to achieve results directed at satisfying the political interests of organizational actors, policy makers and / or controllers, and / or external stakeholders. The second possible goal is realized by increasing real performance, available resources, and organizational competence. Policy objectives are implemented by giving attention and support for the achievement of a particular community policy within the organization.

Wechsler and Backoff (in Suwarsono, 2012: 87) argue that there are four types of strategies that are named as typology of WB model strategies. One of these types of strategies is a development strategy, namely a strategy that is said to be a development strategy if the organization deliberately designs a strategy that wants to leave the status, capacity, and resources behind which in the end will give birth to a new, different organizational posture in the future. The organization is fully put and operated in a development mode.

Wilujeng (in A. Naway, 2016: 46) strategy is a program in order to carry out the mission and to achieve organizational goals. The strategy here in the use of organizational resources is a guide that 
will be used in order to achieve goals and form an integrated direction of all organizational goals. The following are certain steps that can be taken in developing a strategy:

1. Set goals;

2. Set size;

3. Eliminating the differences that occur;

4. Choose an alternative;

5. Pestrategic planning implementation;

6. Measure and monitor progress.

\section{Management strategy}

Management strategic is a series of actions used to formulate, implement, and evaluate managerial decisions in achieving company goals. Strategy has a close relationship with the concept of planning and decision making, so that in the end the strategy develops into strategic management. The strategy management process consists of several stages, including environmental observation, strategy formulation, strategy implementation and strategy evaluation (Fred, 2004: 132).

The environmental observation stage is carried out to identify various environmental events, developments and changes that affect organizational conditions. The strategy formulation stage is the stage of selecting decisions in the selection of alternative strategies to be used by the organization. The strategy chosen is the result of observing the organizational environment. The next stage is the strategy implementation stage, which is the strategy implementation stage that has been formulated or planned. Strategy implementation is a process by which management realizes its strategies and policies through the development of programs, budgets and procedures.

Chandler in Umar (2010: 16) states that strategy is a tool to achieve company goals in relation to long-term goals, follow-up programs and resource allocation priorities. The same thing was conveyed by Stephanie K. Marrus in Umar (2010: 16) who said that strategy is a process of determining the plans of top leaders who focus on the long-term goals of the organization, along with the preparation of ways or efforts how to achieve these goals.

Hamel and Prahalad (Umar, 2010: 17), Strategy is an action that is incremental (always increasing) and continuous, and is carried out based on the point of view of what customers expect in the future. Thus, strategy always starts with what can happen and not what happens. The occurrence of new market innovation speeds and changing consumer patterns requires core competencies. Companies need to look for core competencies in the business they are doing.

Based on some opinions of experts about the definition of strategy above, it appears that the concept of strategy has various meanings.

1. Strategy Function

Assauri (2016: 7), argues that the function of strategy is basically trying to implement the strategy formulated effectively. For this reason, there are six functions that must be performed simultaneously, namely: (1) Communicating a purpose (vision) to be achieved to others. (2) Linking and exploiting current successes and successes while exploring new opportunities. (3) Take advantage or exploit the successes and successes that are obtained now as well as investigate new opportunities. (4) Generating and generating more resources than are currently used. (5) Coordinating and directing future activities or organizational activities. (6) Responding and reacting to new situations at all times.

2. Forms of Strategy

Umar (2010: 17) argues that there are three levels or levels of strategy, namely: (1) Corporate Strategy, this strategy describes the overall direction of the company regarding the company's general attitude towards growth direction and management of various businesses and product lines to achieve a balanced product portfolio. and services. (2) Business Unit Strategy, this strategy is usually developed at the division level and emphasizes improving the competitive position of the company's goods or services in the industry or market segment served by the division. Business strategy generally emphasizes increasing production and sales profits. The business strategy that is implemented is usually one of the overall cost leadership strategies, or differentiation. (3) Functional Strategy, This strategy emphasizes primarily on maximizing productivity resources. Within the boundaries of the companies and the business strategies around them, functional departments such as the Marketing, Human Resources, Finance, Production-Operations functions 
develop strategies to bring together their various activities and competencies to improve the company's performance.

Koteen in Salusu (2008: 104) there are four types of strategies, namely: (1) Organizational Strategy (Corporate Strategy), this strategy is related to the formulation of new strategic missions, objectives, values, and initiatives. Restrictions are needed, namely what is done and for whom. (2) Program Strategy, this strategy pays more attention to the strategic implications of a particular program. What would be the impact if a certain program was launched or introduced, what would be the impact on organizational goals. (3) Resource Support Strategy. This resource strategy focuses on maximizing the use of available essential resources to improve the quality of organizational performance. These resources can be in the form of manpower, finance, technology, etc. and (4) Institutional Strategy. The focus of an institutional strategy is to develop organizational capacity to carry out strategic initiatives.

Researchers argue that in general, the forms of strategy that have been stated earlier outline the same thing, namely the level or type of strategy that can be used to develop an organization. It can be concluded that a strategy is a plan in the form of action used by an organization in realizing the organizational goals that have been set.

\subsection{Village-Owned Enterprises (BUMDES)}

Village-Owned Enterprises (BUMDes) which is defined in Article 1 number 6 of Law Number 6 of 2014 concerning Villages as: "Village-Owned Enterprises, hereinafter referred to as BUMDes, are business entities which are wholly or most of their capital owned by the Village through direct participation. derived from separated Village assets in order to manage assets, services and other businesses for the maximum welfare of the Village community."

Village-Owned Enterprises (BUMDes) as written by Garnies Lellyana Sagita in her research that BUMDes is a village business institution managed by the community and village government in an effort to strengthen or improve the village economy and is formed based on the needs and potentials in the village. BUMDes are a pillar of economic activity in the village that functions as a social and commercial institution.

Law Number 6 of 2014 concerning Village Chapter X Article 87 paragraph 1 stipulates that BUMDes are formed by the Village Government to utilize all economic potential, economic institutions, and potential human resources in order to improve the welfare of the Village community. Specifically, Village-Owned Enterprises cannot be equated with legal entities such as limited liability companies, $\mathrm{CV}$, or cooperatives. BUMDes is a village-characterized business entity which in the implementation of its activities assists the implementation of the Village Government, besides that it also meets the needs of the Village community. BUMDes can also carry out service functions, trade, and other economic development. In increasing the source of village income, BUMDes can collect savings at the local scale of the village community,

BUMDes in its management is not only oriented towards financial benefits but also oriented to support the improvement of the welfare of the Village community. It is hoped that BUMDes can develop business units in harnessing economic potential. Business activities in this case can run and develop well, it is very possible when BUMDes follow the legal entities that have been stipulated in the provisions of the legislation.

Government Regulation Number 43 of 2014 concerning the implementation of Law Number 6 of 2014 concerning Villages, is explained in article 132 that BUMDes are established based on village deliberations, which are then stipulated in the Village Regulation. The BUMDes management organization is separate from the government organization consisting of operational advisors and executors. The village head is an ex-officio advisor, while the operational executive is an individual who is appointed and dismissed by the village head.

Esthabilishment of BUMDes is accompanied by the conception of the Village Tradition which is one of the fundamental ideas. The Berdesa tradition is parallel to the wealth of social capital and political capital and affects the resilience and sustainability of BUMDes (Putra, 2015: 11-12). In the establishment of BUMDes, the core idea of the Village Tradition was:

1. BUMDes needs social capital (cooperation, solidarity, trust, and the like) for a more inclusive and broader business development; 
2. BUMDes develops in inclusive politics through the praxis of Village Deliberations as the highest forum for the development of village economic enterprises driven by BUMDes;

3. BUMDes is a form of village economic enterprise that is collective between the village government and the village community. The collective village economic efforts carried out by BUMDes contain elements of social business and economic business;

4. BUMDes is a business entity mandated by the Village Law as an effort to accommodate all activities in the economic sector and / or public services managed by the Village and / or cooperation between villages;

5. BUMDes becomes a learning arena for Village residents in forging managerial capacity, entrepreneurship, good village governance, leadership, trust and collective action;

6. BUMDes transformed programs initiated by the government (government driven) into village property.

\subsection{Impact of BUMDes in strengthening community economy}

In the Big Indonesian Dictionary (KBBI), impact means a strong influence that can have an effect (positive or negative). The establishment of BUMDes as mentioned in the PDTT Permendes Number 4 of 2015 concerning the Establishment, Management, Management and Disbanding of VillageOwned Enterprises (BUMDes), has several objectives, namely:

1. Improve the village economy;

2. Optimizing village assets to benefit the welfare of the village community;

3. Increasing community efforts in managing the economic potential of the village;

4. Develop plans for cooperation between villages and / or with third parties;

5. Creating market opportunities and networks that support the public service needs of citizens;

6. Opening up employment opportunities;

7. Improve community welfare through improved public services, growth and even distribution of the village economy;

8. Increase the income of the village community and the village's original income.

The people's economy is an economy that is dominated by most of the Indonesian people and owned by the small people. Developing a populist economy means developing an economic system that is based on the people by the people and for the people. Building a community economy means developing and dominating its potential in order to increase the capacity of the community, or with other purposes to empower it. Mobilization of resources is an effort to develop the economic potential of the people. This will increase the productivity of the community, so that both natural resources and human resources around the community can be extracted and utilized. Thus, in a participatory manner, the community and its environment are able to produce and foster added value that increases their prosperity and welfare.

According to Mubyarto (1997: 114), there are three aspects that can be seen from the development of the people's economy, namely:

1. Creating an atmosphere or climate that allows people to develop their potential. The starting point of his thinking is the recognition that every potential that can be developed must be owned by every human being. There is absolutely no society that is helpless;

2. Strengthening the economic potential of the community. In order to strengthen the economic potential of the people, increasing the level of education and health status is a very important effort and opens up opportunities to take advantage of economic opportunities;

3. Developing the community economy also means protecting the community and preventing unequal competition, as well as preventing the exploitation of the strong economic groups over the weak. Staying within the framework of the empowerment process and the development of its initiatives is an effort to protect the community.

\section{Research methodology}

This research is a type of qualitative descriptive research. Qualitative method is a method used to obtain in-depth and meaningful data (actual data, as well as definite data that contains value behind the visible data). In descriptive form research is research that seeks to describe a symptom, event, and incident that is happening now. Descriptive research when the research is ongoing tends to focus on 
actual problems. In determining the research location, the researcher chose to do this research in Naimana Village, Central Malaka Sub-District, Malaka Regency.

In this study, the technique of determining informants used was purposive sampling, namely determining informants with certain considerations so that they were appropriate to be informants. Selection of samples based on certain characteristics with consideration of population characteristics. The informants in this study were the Village Government, BUMDes administrators, managers of savings and loan businesses and village residents (in this case, residents who are or have borrowed from a Satu Hati savings and loan business). Data collection techniques used in this research are observation, in-depth interviews and documentation.

The sources of data in this study are primary data and secondary data. The data analysis process uses the theoretical basis of Miles and Huberman (in Sugiyono, 2015: 338-345): residents who are or have borrowed from a Satu Hati savings and loan business). Data collection techniques used in this study are observation, in-depth interviews and documentation. The data analysis process uses the theoretical basis of Miles and Huberman (in Sugiyono, 2015: 338-345):

1. Data collection

The initial process in qualitative research is the collection of data in the field, both the results of observations, interviews and documentation.

2. Data Condensation

There are quite a lot of data obtained from the field, therefore it is necessary to record it carefully and in detail. As already stated, the longer the researcher goes to the field, the more data will be, complex and complicated. For this reason, it is necessary to analyze data through data condensation immediately. Condensing data means summarizing, combining some data, focusing on the things that are important, looking for themes and patterns and removing unnecessary. Thus the data that has been condensed will provide a clearer picture, and make it easier for researchers to carry out further data collection.

3. Data Presentation (Data Display)

PenyaData in qualitative research can be in the form of brief descriptions, charts, relationships between categories, flowcharts and the like. In this case Miles and Huberman also stated that what is most often used to present data in qualitative research is narrative text.

4. Conclusion Drawing Verification

Conclusions in qualitative research may be able to answer the formulation of problems formulated from the start, but maybe not, because it has been argued that the problems and problem formulations in qualitative research are still temporary and will develop after the research is in the field. The conclusion in qualitative research that is expected is a new finding that has never existed before. Findings can be in the form of descriptions or descriptions of an object that was previously dim or dark so that after being examined it becomes clear, it can be in the form of causal or interactive relationships, hypotheses or theories.

In analyzing the data, the researcher must first determine whether the data found is accurate or not. The validation of the finding data in qualitative research according to Cuba (in Indrawan and Yaniawati., 2014: 153) includes several criteria, namely: Credibility, Transferability, Dependability, and Confirmability. a data in qualitative research can be accounted for as previous scientific research needs to be tested for the validity of the data. In this study, researchers used the Credibility criteria to validate the data. Credibility (Credibility) or a test of confidence in the research data presented by the researcher so that the results of the research carried out are not dubious as a scientific work done by means of source triangulation, data collection technique triangulation and time triangulation (Sugiyono, 2015: 273).

\section{Results and discussions}

In connection with the explanation related to the theory in this study, in analyzing research problems regarding the management strategy of Satu Hati savings and loan business in VillageOwned Enterprises (BUMDes) in Naimana Village, Central Malaka Sub-District, Malaka Regency, the authors use the stages or process management strategy model Hunger \& Wheelen 2007: 138) which consists of environmental observations (internal and external), strategy formulation, strategy implementation and strategy evaluation and will be related to the following research results:

\subsection{Internal environmental observations}


Observation of the internal environment must be carried out so that researchers can see and observe the phenomena that are happening in the Satu Hati BUMDes savings and loans organization, because a little more of these phenomena can affect the existence of the organization.

1. Education level of the manager of a saving business

Education level must be reflected in attitudes and behavior. Attitude and behavior is a form of personality that can beliveseen and observed. Attitude is a person's personality in thinking and becomes the basis for behavior, while behavior is an expression that is expressed in the form of an action. In choosing the management of the Satu Hati BUMDes, one of the conditions is that it mustHaving an honest attitude, being active, skilled and dedicated to the prosperity of the "Satu Hati" BUMDes. Naimana Village CommunityAs, a borrower of funds through the Satu Hati BUMDes savings and loan business, the management of the Savings and Loans Business at Satu Hati BUMDes, is quite good and open in carrying out the tasks assigned to them. The level of education of the Satu Hati BUMDes administrators is reflected in their attitudes and behavior so that in its implementation the management is close enough to the community so that the community becomes comfortable and is not ashamed to borrow funds from Satu Hati BUMDes.

2. Communication

Communication is a form of two-way conversation between residents and residents as borrowers, residents with BUMDes administrators, fellow BUMDes administrators, and BUMDes administrators with the Naimana Village Government. Good communication must be initiated by one party so that it can be responded to by the other party and if the communication does not go well or only in one direction it will cause many problems and this happens in Satu Hati BUMDes, namely the communication that has been carried out so far has always been smooth. The level of communication that is carried out is always two-way between Satu Hati BUMDes management and residents as borrowers so that the flow of cooperation between the two parties becomes conducive.Communication regarding how to policy Satu Hati BUMDes communicated to the organization and / or the public, in this case the public Naimana Villageand the attitudes and responses of the parties involved. in its implementation, communication is critical to the success of achieving the goals of the Satu Hati BUMDes. Apart from that, it is required that the communicated policies must be precise, accurate and consistent.

3. Cooperation

In an organization, cooperation is needed so that the goals of the organization can be achieved. Cooperation is a real act of communication. Collaboration between residents and management in the process of borrowing and returning loan funds; cooperation between administrators in terms of socializing savings and loans to villagers so that villagers know, understand and want to borrow from a savings and loan business; cooperation in terms of collecting bad loans. Collaboration is needed because this savings and loan business is not a permanent job for the management, so it is necessary to complement one another. In this research it is known that the cooperation that is carried out is good and some does not run smoothly, this happens because the perceptions of each community as a beneficiary are different about the interests that are obtained by each community itself. People who say that the cooperation is not good because the community does not benefit from the cooperation activities carried out with Satu Hati BUMDes, while people who say that the cooperation is carried out can be said to be good because they have benefited from the collaboration carried out with Satu Hati BUMDes.

4. Binding and governing rules

In order for an organization to run well, there must be rules that underlie it, so that what is done must be in accordance with applicable rules. This also applies to the Satu Hati BUMDes savings and loans business. In carrying out its work program, Satu Hati BUMDes must be able to form a set of rules to bind savings and loan business managers and community members as borrowers so that the savings and loan business can run well. In its implementation, BUMDes fund managers and borrowers have not been able to afford it have not made a legal and binding rule between the borrower and the management so that the borrower does not know when the due date is, what documents must be completed, the requirements for borrowing are anything. This also improves the performance of the Satu Hati BUMDes organization whereas if traced, in order for an organization to run well, there must be rules that underlie it, so that what is done must be in 
accordance with the applicable regulations, but this does not happen in the implementation of Satu Hati BUMDes activities so that it also hinders the implementation of a good organization.

\subsection{External environmental observations}

Observation of the external environment must also be done so that researchers can find out what phenomena occur outside of the savings and loan business organization at Satu hati BUMDes that can affect the development and progress of the organization itself.

1. Borrower's education level

In understanding something that is needed is a mature mindset and can be seen from the level of one's education. The higher the level of education, it is believed that the easier it will be for them to understand and run the funds from the savings and loan business at Satu Hati BUMDes, Naimana Village. In its implementation, the borrower's education level is not problematic and has no effect because it all depends on individuals to manage their respective loan funds. The management of the Satu Hati BUMDes stated that they only serve people who really need these funds. The management does not see the level of education. The important thing is that they want to borrow funds from the Satu Hati BUMDes Savings and Loan Business that is enough. The management of these loan funds depends on their personal. This consideration was made because the average person in Naimana Village only has senior high school education, if the management of the Savings and Loans Business uses a standard level of education, it is likely that there will be no community willing to borrow from Satu Hati BUMDes. The administrators of Satu Hati BUMDes are only guided by the ability of the community to manage money.

2. Tradition

Tradition is a habit that must be preserved. This is not without cause. Tradition is seen as something good and has been done for a long time so that people must consciously participate in it. There are many forms of tradition, some in the form of family gatherings, the dead, marriage, thanksgiving and so on. In supporting the tradition process, of course, the community is obliged to provide a certain amount of money, goods or animals so that their names will be recorded in the donation book. Tradition are quite influential if the main purpose of borrowing is to take part in customary events. So that automatically the funds that have been borrowed are immediately used for traditional events.

3. Lifestyle

Lifestyle is a tendency to follow what is the current trend. Lifestyle today is seen as a necessity so that not seen as less capable and able to adapt to the surrounding community. The style referred to is the use of cellphones, motorbikes, gold items (rings, necklaces, bracelets, earrings), expensive clothing and accessories. Lifestyle is often seen as a secondary need and some even think that lifestyle is a must. This is what is considered to affect the repayment of loan funds in this Satu Hati BUMDes saving and loan business. In this study, lifestyle is less influential because it is only a temporary necessity and only to be recognized by society.

4. Competitor

The community as a marketing target makes the same organization a competitor for Satu Hati BUMDes in Naimana Village saving and loan business promote savings and loan business products. Public interest in borrowing from the BUMDes savings and loan business can be divided because of offers and promises from competing businesses. The intended competitors are individuals, cooperatives and banks. The offer can be in the form of a larger loan amount, smaller loan interest, time return longer funds, easy administration, and many other offers. There have been many similar organizations in Naimana Village that have contributed to the implementation of Satu Hati BUMDes activities.

5. Political Policy

Political policy is often seen as siding with relatives, acquaintances and close people or to people who have higher positions. In the village administration, we can see who the people who receive assistance are, whether it is appropriate or not that the person receives it if it is adjusted according to the existing criteria. Politics on policies within organizations also often occur, this does not rule out the possibility that politics may also influence policies in the Savings and Loans Business at this Satu Hati BUMDes. This can also affect the repayment of funds that have been borrowed, because the management will be reluctant to collect these loans if there is politics in the policy of 
determining who can receive this loan. It is known that in the implementation there are no policies that are political or take sides with certain people as borrowers.

From these results it can be stated that before an organization can formulate a strategy, it must first make environmental observations. Environmental observations are carried out to identify various events, developments and environmental changes that affect organizational conditions (Hunger \& Wheelen, 2003). Environmental observation is divided into two, namely the external environment and the internal environment. External environmental observation is carried out to identify opportunities and threats faced by the organization. This is in line with Jauch and Glueek (1999: 87) who state that environmental analysis is a process used in strategic planning to monitor the environmental sector in determining opportunities or threats to companies. Meanwhile, internal environmental observations are carried out to identify the strengths and weaknesses of the organization. Environmental observation is the acquisition and use of information about events, trends, and relationships in an organization's external environment, which is knowledge that will help management plan future actions.

Furthermore, Dess and Miller (1996: 57) argue that the environment plays an important role in determining the fate of the entire industry as well as individual businesses. The most basic principle for strategic management is that the manager or leader of the organization must adapt its strategy to the influence of the environment in which the company operates.

Observing the environment is an activity of monitoring, evaluating and disseminating information to important people in the company based on the results of external and internal environmental observations. Companies make environmental observations to avoid sudden strategic actions (strategic surprice) and to ensure the long-term sustainability of the organization.

If this is related to the Savings and Loans Business at Satu Hati BUMDes, the question will arise that what are the advantages and disadvantages of the Savings and Loans Business at Satu Hati BUMDes and what threats can make the Savings and Loans Business at Satu Hati BUMDes become stuck and maybe until it's closed.

Weaknesses that are already known should be corrected and enhanced and the advantages that are already owned should be maintained and improved so that Savings and Loans at Satu Hati BUMDes can face threats from outside this organization. The stability of an organization depends on its existence, if the organization does not exist, it may stop running over time.

\subsection{Strategy formulation}

The organization will use strategy formulation, namely the process of determining alternative strategy decisions in achieving the organizational goals of the savings and loan business. The subfocus that wants to be investigated are: legal rules for managing savings and loans; and Determining the Vision and Mission of the savings and loan business organization.

1. Legal rules for managing savings and loans (legal entities)

Organization is called as a legal organization if there is an AD/ART and it is legalized by a notary so that automatically the organization is a legal entity and its legality can be accounted for. An organization that is a legal entity must have legal rules and regulations thatgood so that all activities carried out in the organization can run within the rules that have been made. The Satu Hati BUMDes, as an organization that has been formed with the Naimana Village Head Decree, must be able to make a special rule in the management of each section, so that each section can work according to the flow and there are rules that govern it. In practice it is known thatthere is already a notary certificate but it has not been poured into the poko rules such as what files must be completed, what is the minimum and maximum amount of funds that can be accommodated to be borrowed, the loan period.

2. Determination of the Vision and Mission of the Organization

Vision and mission are the goals and plans of an organization so that it can run well. Satu Hati BUMDes as an organization must also have a vision and mission. The vision and mission must be conveyed to the community so that they also know about the plans and objectives for establishing this BUMDes in their village. The determination of the vision and mission already exists but it has never been disseminated to the community so that there are no people and even some of the management do not know. This has resulted in all the strengths of the Village of Naimana not being maximally integrated into a single unit of support for realizing the welfare and independence 
of the village through Satu Hati BUMDes. There are several factors that cause this to happen, namely; First, the process of mutilation and amputation of political, social and economic power in the village was carried out by supra villages, through various means, including through the mechanism of "politicization of development", politicization of budgets and technocratization of planning. The second factor, namely, low awareness of village elites (political figures, social leaders, traditional leaders, religious leaders, village entrepreneurs, etc.) collaborate and elaborate in formulating joint steps to realize village progress by optimizing the use of the Satu Hati BUMDes. This is also due to the first factor above, and also low social capacity, as well as the elitist and closed behavior of village government administrators. The third factor is the lack of awareness and empowerment of the village youth generation to be actively involved in developing the village.

3. Loan interest

Loan interest is an additional fee charged to borrowers with an agreed upon amount. The loan interest rate for this Satu Hati BUMDes is $8.25 \%$ and applies to all loan sizes. The amount of loan interest can be an effective strategy to attract people to want to borrow from the Satu Hati BUMDes Savings and Loan Business. Noted that the loan interest is light enough. The hope of the community is not to raise loan interest rates again so that the community can be helped because the main objective of holding this Satu Hati BUMDes is based on the collective initiatives and initiatives of the Naimana Village community so that it is hoped that the increase in loan interest will not occur because it will automatically suffer the people of Naimana Village itself and this is contrary to the main objective of establishing Satu Hati BUMDes in Naimana Village.

4. Penalty and Rewards

Penalty and rewards are two different things. Penalty is given to borrowers who do not repay the loan until the time limit has been given while the award is given to borrowers who pay off their loan funds on time. The clarity of witnesses and awards is one concrete manifestation that Satu Hati BUMDes is an organization whose legality is clear and this can also bind the borrower and $B U M D e s$ so that the borrower can consciously repay the loan according to the agreement because it has been bound in a legal agreement in administrative and legal aspects. In implementation, there have been no written penalty and rewards so that so far the borrowing community has been willing to deposit or repay the borrowed funds.

5. Training for body management and local community

Training body management and local community is something that is no less important. Usually training is carried out so that people who are trained can apply the material that has been received during the training in their daily activities. BUMDes management capacity training is also in the form of management procedures, systems, activities and how to select market shares for products that are issued. In addition, the administrators were also trained in management procedures starting from formation and planning to implementation, however, in its implementation by Satu Hati BUMDes in Naimana Village, it is known that no training has ever been carried out so it is necessary to do and involve the community in order to grow a sense of belonging in the community.

\section{Conclusion}

Based on the results of the research and discussion that has been described, this research can It was concluded that the existence of a savings and loan business at Satu Hati BUMDes In Naimana village has been enough to help people who really need funds in terms of increasing family income. This is clearly in accordance with the objectives of the BUMDes organization, namely improve the Economy of Village Communities.

Based on the results of the interviews that have been conducted, it can be concluded that:

1. Environmental observations carried out in the organization in the form of weaknesses in the Satu Hati BUMDes saving and loan business, it is known that communication between the current administrators is not going well so that administrators tend to run and work individually. The absence of rules that govern and regulate this savings and loan business has made the community manage the funds that have been borrowed arbitrarily even though they are not in accordance with their initial needs. In the absence of a governing rule, only situational organizational policies are carried out so that the Satu Hati savings and loan business can run. Record keeping and 
bookkeeping have been done but there are borrowers who say that they have made deposits but have not been recorded.

Environmental observations carried out outside the organization in the form of threats from outside the Satu Hati BUMDes saving and loan business, it is known that the borrower's education level has no effect on the repayment of funds that have been borrowed. Customs are very closely related to the existence of a person in their environment so that it is something that cannot be refused or avoided and is a must, naturally customs can influence someone in managing their finances, this also applies to borrowers of funds in the Satu Hati BUMDes saving and loan business. There are already many organizations that are the same as the Satu Hati BUMDes savings and loan business in Naimana Village, so a good strategy formulation is needed so that the organization continues to exist and is not affected by the same competitors. In Satu Hati BUMDes saving and loan business, there is no political intervention or policy in favor of certain people. These external threats must be quickly addressed so that these threats can be turned into strengths in Satu Hati BUMDes saving and loan business.

2. The formulation of strategies related to the legal rules for managing savings and loans (legal entities) has been limited to the existence of a Notary Act. Determination of the Organization's Vision and Mission already exists but has never been disseminated to management and the community so that what the organization wants is not known by the community. Loan interest is considered quite small and is very helpful and provides relief to the borrowing community. There are no sanctions or awards so that people are still free to manage funds that have been received and used at will, but this has resulted in the repayment rate of loans being hampered and stalled.

\section{Limitation and study forward}

This research only examines the formulation Management Strategies for Savings and Loans at Satu Hati Village-Owned Enterprises (BUMDes) in Naimana Village, Central Malaka SubDistrict, M Regency. Suggestions given in this study are that there is a need for legal clarity and rules in the savings and loan business so that funds lent to the public can be returned on time. There is a need for socialization to the public about the Satu Hati BUMDes Savings and Loan Business. As soon as possible solve the problems that are happening so that the Satu Hati BUMDes organization can continue to exist.

\section{References}

A. Naway, Fory. (2016). Strategi pengelolaan pembelajaran. Gorontalo. Ideas Publishing.

Assauri, Sofjan. (2016). Manajemen operasi produksi (pencapaian sasaran. organisasi berkesinambungan). Edisi 3. Jakarta: PT Raja Grafindo Persada

BUMDes Satu Hati. (2019). Financial report recapitulation. Naimana

Dess, Gregory G. and Alex Miller. (1996). "Strategic Management". International Edition,. New York: Mc Grow Hill.

Fred R. David. (2007). Strategic management. New Jersey: Prentice Hall Inc.

Hunger, J. David \& Thomas L. Wheelen. (2004). Strategic management. Yogyakarta. Andi

Indrawan, R. \& Yaniawati R.P. (2014). Metodologi penelitian kuantitatif, kualitatif, dan campuran untuk manajemen, pembangunan, dan Pendidikan. Bandung: Penerbit PT Refika Aditama

Jauch Lawrence R. \& Glueck William F. (1989). Manajemen dan strategis. Kebijakan Perusahaan. Jakarta: Erlangga.

Mubyarto. (1997). Pengantar ekonomi pertanian. LP3ES: Jakarta. Universitas Sumatera Utara

Muhamad Suwarsono. (2012). Strategi pemerintahan: manajemen organisasi publik. Jakarta. Erlangga

Pemerintah Desa Naimana. (2017). Peraturan Desa Naimana No. 3 Tahun 2017 tentang Pendirian Badan Usaha Milik Desa.

Pemerintah Indonesia. (2014). Undang-undang No. 6 Tahun 2014 tentang Desa. Lembar Negara. No. 7. Sekertariat Negara.Jakarta.

Pemerintah Indonesia. (2014). Peraturan Pemerintah Republik Indonesia No. 43 Tahun 2014 tentang Peraturan Pelaksanaan Undang-undang No.6 Tahun 2014 tentang Desa. Lembaran Negara. No. 123. Sekertariat Negara. Jakarta. 
Permendes, P. D. T. T. no 4 tahun 2015 tentang Pendirian. Pengurusan dan Pengelolaan dan Pembubaran BUMDes.

Putra, A.S. (2015). Badan Usaha Milik Desa: Spirit usaha kolektif desa (cetakan pertama). Jakarta: Kementrian Desa, Pembangunan Daerah Tertinggal, Dan Transmigrasi Republik Indonesia.

Salusu, J. (2008). Pengambilan Keputusan Stratejik. Jakarta: PT Gramedia Pustaka Utama

Steiner, George A. \& John B. Miner. (1997). Kebijakan dan strategi manajemen (Edisi Kedua). Jakarta: PT. Gelora Pratama.

Sugiyono. (2015). Metode penelitian pendidikan pendekatan kuantitatif, kualitatif dan $R \& D$. Bandung: Alfabeta.

Umar Husein. (2010). Riset Sumber Daya Manusia dalam organisasi. Gramedia. Pustaka Utama, Jakarta. 